\title{
The Benevolent Fund
}

The fund can mean the difference between survival or not; the difference between despair or hope; or the difference between knowing that someone else really does care.

The details of the cases used in this leader have been changed to protect the identities of the individuals concerned.

Mike Grace e-mail: m.grace.bdj@bda-dentistry.org.uk

\section{$\mathbf{T}$} This year my wife and I left the BDA Conference at Torquay with a new addition to our home, a cuddly toy bear affectionately known as Ben Bear. I suspect many other people did the same, because Ben is extremely likeable. Perhaps of more importance though, Ben's arrival in homes will make significant differences to those people that the BDA Benevolent Fund assists every year because he is one of the latest ways of raising funds.

Most UK dentists know the Benevolent Fund well, mainly because of the raffles held at BDA Section and Branch Meetings, the diaries we have been buying as long as we can remember and the Christmas Raffle that slips through our letter box each year now. But for some people, either dentists or their close families, the Benevolent Fund means much more than a few pounds given away - it can mean the difference between survival or not; the difference between despair or hope; or the difference between knowing that someone else really does care.

For example, let us consider some of the cases that have been helped in the past. The first is a dentist who was unable to obtain health insurance following an accident. She had built up two practices and was coping with the same hassles we all cope with when the accident totally ruined her future. Another example is the dentist in his fifties with a neurological disorder that prevents him from practising, and who has just had his permanent health insurance withdrawn after years of support. A third example is the single mother in her forties who, following a serious heart attack, is unable to work any more. A fourth is the dentist who sits in his (or her) car outside the practice each day plucking up the courage to go in - often bursting into tears at the thought and not understanding why.

In each case the Benevolent Fund is there to help. The Fund, set up in the early 1880s just after the formation of the BDA, provides care for dentists and their families who, through no fault of their own, find themselves in desperate circumstances. Any dentist on the UK Dentists Register is eligible for help, and each case is considered on its merits. Sometimes it is not the people themselves who make the first approach (pride is understandable in these cases as often it is all people have left) but a friend, colleague or perhaps a social worker. The administrator of the Fund, Sally Atkinson, can be contacted through the BDA or on 01714864994 which is a confidential/dedicated phone line. She will tactfully gather the information required for the Trustees to decide if the case merits help.

Sometimes the help is short term, seeing people through a bad patch until they can support themselves. Sometimes the help continues, as in the case of the longest beneficiary who has been helped since 1959. The fund had 24 new cases last year and is already up to 18 this year. However, unlike the popular misconception of the fund mainly helping elderly widows, a growing number of requests are from young dentists, some finding the stress of modern dentistry too much to cope with. Last year $50 \%$ of cases were linked to stress, and in many of these cases the fact that someone actually listens can be more important than the financial assistance.

For most of us, despite what we like to believe, life has a habit of handing us a nasty surprise every so often. Yet we behave as if the good times will continue to roll until the surprise hits us - and it is not possible to insure for every eventuality or cope with every setback, however well-prepared we are. The BDA Benevolent Fund was set up by people who believed that it is important for those fortunate enough not to have suffered from the totally unexpected to provide some help for those who find themselves with unforeseen difficulties. That spirit of charity, in the true sense of the word, continues today. Long may it continue, and long may ideas such as Ben Bear provide the means for the rest of us to help. 